\title{
Preventive Behaviour to Obesity in Elementary School Students in Surabaya, Indonesia
}

\author{
Rif'atin Haibah' ${ }^{1)}$, Muji Sulistyowati ${ }^{1)}$, Ismayani ${ }^{2,3)}$ \\ 1 Department of Health Promotion and Behavior Science, Faculty of Public Health, Universitas \\ Airlangga, Surabaya, Indonesia \\ 2 East Java Provincial Health Office, Surabaya, Indonesia \\ 3 Indonesian Society for Health Promotor and Educator (ISHPE), East Java, Surabaya, Indonesia \\ Email: rifatin.haibah-2017@fkm.unair.ac.id
}

\begin{abstract}
Background: Overweight and obesity are two of the main non-communicable disease risks, causing mortalities in developed and developing countries. Obesity is a condition of excessive body fat, which causes overnutrition and obesity in children increases each year. Child obesity raises physical health problems that have the impact on the quality of life and the child's body development. Moreover, it potentially makes children suffer from diseases. Purpose: This study aims to identify the related factors of preventive behavior for obesity among elementary school students in Surabaya by using the Health Belief Model Theory. Methods: This study was a cross-sectional study, which involved 104 elementary school students in fourth and fifth grade in SD Dr. Soetomo V, Surabaya as samples. These samples were taken with simple random sampling. The independent variables in this study were perceived susceptibility, perceived severity, perceived benefits, perceived barriers, self-efficacy and cues to action. While the dependent variable was preventive behavior for obesity. Data were analyzed by using double logistic regression after the candidates selectionwith $p<0.25$ was obtained from the analysis of dependent and independent variables. Results: The results show that perceived susceptibility $(P$ Value $=0,262)$, perceived severity $(P$ Value $=0,967)$, perceived barriers $(P$ Value $=0,255)$, and cues to action $(P$ Value $=0,565)$ does not have a correlation with preventive behavior for obesity among the students. Factors related to preventive behavior for obesity were perceived benefits $(P$ Value $=0,037)$ and self-efficacy $(P$ Value $=$ $0,037)$. Conclusion: The factors which are related to preventive behavior for obesity among the students at Dr. Soetomo V Elementary School, Surabaya are perceived benefits and self-efficacy.
\end{abstract}

Keyword: Students, Obesity, Preventive Behaviour, Health Belief Model

\section{INTRODUCTION}

One of the health issues in the developing countries that can cause disruption of physical growth and development is obesity. Overweight is a situation when a bodyweight and height overly grow beyond the normal state (overweight), while obesity is a condition of excessive body fat as a result of an over-plus amount of calories that triggers various diseases to emerge inside the body (Prihaningtyas et al., 2018). Those two physical problems are the main noncommunicable disease risks, causing mortalities in developed and developing countries. The amount of over-nutrition and obesity prevalence in children increases each year. Child obesity causes physical health and mental problems that have the impact on the quality of life and the child's physical development. Moreover, it potentially makes children suffer from diseases in the future.

The obesity problem among children between 5-12 years old, it shows that the number had been doubled since 2010 which is $18.8 \%$, in which the percentage consists of $10.8 \%$ overweight category and $8.8 \%$ obesity category (Kementerian Kesehatan Republik Indonesia, 2013). Prevalence of nutrition status among children with age between5-12 years old, based on the sex characteristic shows that the percentage of overweight among boys is $10.4 \%$ and the percentage of girls is $11.2 \%$, meanwhile the obesity percentage for 
boy category is $10.7 \%$ and $7.7 \%$ among girls (Kementerian Kesehatan Republik Indonesia, 2018).

Other research shows that several factors can cause obesity among children, including dietary habits, physical activity, allowance, and parental physical fatness (Wulandari, Lestari and Fachlevy, 2016). It is supported by another research result by the Ministry of Health in 2018, the activity proportion among citizens increases from $26,1 \%$ to $33,5 \%$, and the proportion of vegetable consumption by citizens older than five years old stays at 95\% (Kementerian Kesehatan Republik Indonesia, 2018).

The development of industry and globalization in advanced technology will ease our daily activity that can change our lifestyle in completing our physical activity. The decreasing amount of physical activity will become one factor that causes obesity. This opinion is supported by other research, which stated that children who lack physical activity would experience the risk of obesity as much as 6,388 times compared to children who have enough physical activity (Kosnayani and Aisyah, 2016). The vast spread of fast food and children's habits who consume it regularly will danger their health, parents who lack attention to their children's nutrient condition will raise the risk of that dangerous situation such a dangerous situation. Fast food is a good choice in terms of time management, food hygiene, and easy to find. Dietary habits among children during school time who consume lots of food with high fat, glucose, and calories, supported by their lack of activity, will be a factor for obesity.

The number of children with overweight condition right now is concerning. Obesity and overweight trend among citizens of East Java are increasing, that the province occupies third place after Jakarta and Papua within overweight prevalence among children of 5-12 years old, it is $13,2 \%$, and obesity prevalence is $11,1 \%$ within the bad dietary habit of $\geq 1$ time/day. Children who are older than three years old regularly consume sweet food, sweet beverage consumption, and fat including cholesterol and fried food. Surabaya is one of the cities in East Java that many overweight experiences among students have occurred. The former study at Tambaksari Sub-district, Surabaya showed that phenomenon. It was said that under-nutrition prevalence is about $63,4 \%$, it was bigger than overweight prevalence which is $28,8 \%$, and obesity prevalence which is $34,6 \%$ (Rosyidah and Ririn Andrias, 2015). The result had exceeded its previous study conducted, it stated that overweight and obesity prevalence among elementary school students of SDN Ploso 1-172 Surabaya is about 20\%, consists of 94 students with $18 \%$ overweight and 2\% obesity (Yaqin and Nurhayati, 2014).

Health Belief Model can be used to motivate people to have a healthy habit and positive activity to improve their health by prevention activity. This theory suggests that individual action to prevent or to control illness condition influenced by primary concepts of susceptibility, seriousness, benefits and barriers to a behavior, cues to action, and self-efficacy. Perceived susceptibility is a belief of how susceptible a person to get overweight to obesity. Perceived severity is a hunch about how severe the disease would affect the person toward obesity. Perceived Benefits is an individual belief of the advantage of preventing obesity. Perceived Barriers is an obstacle to preventing obesity. Self-efficacy is the ability to take action and cues to action is a sign that encourages individuals to take action (Glanz, Rimer and Viswanath, 2008). The theory could be implemented towards children, teenagers, or adults (Delisle, Ledoux and Strychar, 2014)

Obesity prevention programs among children can be implemented through dietary habits and patterns and also increase physical activity in dailylife. This study aims to identify related factors of obesity preventive behavior among elementary school students in Surabaya by using the health belief model theory.

\section{METHODS}

This study was analytic observational, with a cross-sectional design. The population was all students in grade 4 and grade 5 in SDN Dr. Soetomo V Surabaya. The total population was 237 students, and total sample were 104. The sample was 
collected by probability of simple random sampling. The independent variables were perceived susceptibility, perceived severity, perceived benefits, perceived barriers, self-efficacy and cues to action. While the dependent variable was preventive behavior for obesity.

Primary data were directly collected through questionnaire where guidance and explanation were given by the researcher in advance. The informed consent was already agreed and signed by parents that allow their children to be the respondents of this study. Secondary data were retrieved by literature study, journal, other sources reference that are related to the study.

Multivariate analysis used in this study was a double logistic regression test. Data were analyzed by using double logistic regression after the selection of candidates with $P$ Value $<0.25$ was obtained from the analysis of dependent and independent variables (Lapau, 2012).

\section{RESULTS AND DISCUSSION}

SD Dr. Soetomo V/327 Surabaya is one of elementary school which is located in Surabaya downtown. During the school year of $2019 / 2020$, the school had 762 students, consists of 378 male and 384 female students. Based on table 1 , it is revealed that $50 \%$ respondents had susceptible toward obesity, 52,9\% respondents assumed that obesity was not something to be worried about, $58,4 \%$ respondents felt the advantages of performing obesity prevention, 53,8\% respondents experienced some obstacles while doing obesity prevention, 52,9\% respondents revealed that they were unable to prevent obesity, and 59,6\% respondents feel to be motivated to do obesity prevention.

Table 2 shows that there are variables that has $P$ Value $<0.25$ value, including Perceived Susceptibility, Perceived Severity, Perceived Benefits, Perceived Barriers, and Self Efficacy. Meanwhile, the variable that has $P$ Value $>0.25$ is Cues to Action. Thus, the candidates in bivariate selection are 5 variables that will be used in the multivariate model.

From the analysis result of table 3 , three variables has a $P$ Value of $>0,05$, namely Perceived Susceptibility, Perceived Severity, and Perceived Barriers. The factors related to preventive behavior for obesity are perceived benefits $(P$ Value $=0.037)$ and self-efficacy ( $P$ Value $=0,037$ ).

Table 1. Tabulation Individual Belief with preventive behavior for obesity

\begin{tabular}{|c|c|c|c|c|c|c|}
\hline \multirow{3}{*}{ Individual Belief } & \multicolumn{4}{|c|}{ To Prevent Obesity } & \multirow{2}{*}{\multicolumn{2}{|c|}{ Total }} \\
\hline & \multicolumn{2}{|c|}{ Do } & \multicolumn{2}{|c|}{ Don't } & & \\
\hline & $\mathbf{n}$ & $\%$ & $\mathbf{n}$ & $\%$ & $\mathbf{n}$ & $\%$ \\
\hline Susceptible & 49 & 47.1 & 3 & 2.9 & 52 & 50.0 \\
\hline No Susceptible & 39 & 37.5 & 13 & 12.5 & 52 & 50.0 \\
\hline Severe & 46 & 44.2 & 3 & 2.9 & 49 & 47.1 \\
\hline No Severe & 42 & 40.4 & 13 & 12.5 & 55 & 52.9 \\
\hline Benefit & 56 & 53.8 & 1 & 1.0 & 57 & 54.8 \\
\hline No Benefit & 32 & 30.8 & 15 & 14.4 & 47 & 45.2 \\
\hline Barriers & 53 & 51.0 & 3 & 2.9 & 56 & 53.8 \\
\hline No Barriers & 35 & 33.7 & 13 & 12.5 & 48 & 46.2 \\
\hline Be able & 48 & 46.2 & 1 & 1.0 & 49 & 47.1 \\
\hline Unable & 40 & 38.5 & 15 & 14.4 & 55 & 52.9 \\
\hline Pushed & 54 & 51.9 & 8 & 7.7 & 62 & 59.6 \\
\hline Not Pushed & 34 & 32.7 & 8 & 7.7 & 42 & 40.4 \\
\hline
\end{tabular}

Table 2. Selection Result of Bivariate

\begin{tabular}{lcc}
\hline \multicolumn{1}{c}{ Independent Variables } & P Value & Information \\
\hline Perceived Susceptibility & 0.014 & Candidate \\
Perceived Severity & 0.028 & Candidate \\
Perceived Benefits & 0.000 & Candidate \\
Perceived Barriers & 0.005 & Candidate \\
Self Efficacy & 0.001 & Candidate \\
Cues to Action & 0.565 & Not a candidate \\
\hline
\end{tabular}


Table 3. The Final Model of Double Logistic Regression Analysis that is Related to Obesity in Dr. Soetomo V Surabaya Elementary School in 2019.

\begin{tabular}{lcccc}
\hline \multicolumn{1}{c}{ Independent Variables } & B & SE & P Value & Odd Ratio \\
\hline Perceived Susceptibility & -0.886 & 0.790 & 0.262 & 0.412 \\
Perceived Severity & 0.35 & 0.863 & 0.967 & 1.036 \\
Perceived Benefits & -2.378 & 1.140 & 0.037 & 0.093 \\
Perceived Barriers & -0.903 & 0.793 & 0.255 & 0.405 \\
Self Efficacy & -2.297 & 1.103 & 0.037 & 0.101 \\
\hline
\end{tabular}

The Relationship between Perceived Susceptibility and Obesity Prevention Action

Perceived susceptibility is a person belief about the possibility of getting a disease or certain conditions (Glanz, Rimer and Viswanath, 2008). The cross-tabulation between Perceived Susceptibility and obesity prevention action displayed in table 1 reveals that there are 49 respondents $(47.1 \%)$ who assume susceptible to obesity and wellperformed obesity prevention. Another 39 respondents $(37.5 \%)$ does not consider susceptible to obesity but still take preventive action. The result of double logistic regression test reveals that there is no relationship between Perceived Susceptibility and obesity prevention action on the $P$ Value of 0.262 ( $P$ Value $>0.05$ ).

Perceived susceptibility is measured in subjective perspective for each individual, thus, every person has different susceptible information based on their belief in dealing with obesity. In this study, a person could be diagnosed with susceptibility if he/she thought that he/she could experience obesity, by always consuming high-fat food and drinking sweet beverages. Respondents who express that they have no obesity assumed that they will have no chance to be overweight and will not experience diseases that come from obesity. It was caused by the good dietary habit and normal weight of their bodies. In this study, 55 respondents $(52,9 \%)$ had normal weight.

Elementary school students are the age group that is very fragile to experience obesity. Moreover, these children have more chances to be overweight because of their poor dietary habits that could lead them to have obesity. They are very easy to be tempted with unhealthy food during or after school time (Nisak and Mahmudiono, 2018). According to previous study in 2016, it is stated that $46,87 \%$ of children often consume fast food, and children who regularly consume fast food have the chance to experience obesity as much as 3,667 times compared to students who barely consume fast food (Junaidi and Noviyanda, 2016).

This study reveals that perceived susceptibility is not related to obesity prevention action. It could happen because of the significant role of mother to set up daily menus to the respondents. Those childrens have an opportunity to choose their food if the mother gives an allowance. Furthermore, if mother and children do not have sufficient information, they will choose the fast food or unhealthy snack. According to previous study, high frequency of junk food consumption among elementary school students are the existence of various kinds of places that sell junk food near schools so that they can be easily accessed (Amalia, Sulastri and Semiarty, 2016). It should be the role of schools to regulate the snacking behavior during school time.

The Relation Between Perceived Severity and Obesity Prevention Action Perceived severity is a personal belief in the perceived threat, the severity of contracting the disease so that they try to prevent the disease to emerge. Even though there are 46 respondents $(44.2 \%)$ who think that obesity is a serious or severe health disorder, but there are $59.9 \%$ of the respondents who deem the opposite. Then, result of the double logistic regression test revealed that there is no relation between Perceived Severity and obesity prevention action on the $P$ Value of 0.967 ( $P$ Value>0.05).

The chance to experience overweight and obesity will be increased at adult age, this will increase the rate factor of non-communicable disease (NCD) such as cardiovascular, diabetes mellitus, osteoarthritis, cancer, etcetera (WHO, 2010). Overweight and obesity 
among children cause several problems that could disrupt their quality of life such as sleep disorder, sleep apnea, and respiratory problems (Kementerian Kesehatan RI, 2012). Children with obesity will experience health disorders that could have a negative impact on the body until they become teenagers and adults.

This information is expected to be caught by respondents. Moreover mother as a manager in the respondents family has a lack of that, too. This analysis is related to Rodríguez-Ventura et al. (2014) that severe level felt by subjects is determined by their level of knowledge about obesity, the disease caused by obesity, lack of parental attention, and the environmental effect that force them to consume fast food.

Moreover, previous study writes that besides knowledge, lifestyle behavior can cause a high frequency of junk food in children. Individuals who have lack of knowledge and understanding of health risks will be related to the poor perceived severity. Mother and school-children should have an accurate information about the risk of fast food intake regarding obesity (Amalia, Sulastri and Semiarty, 2016).

\section{The Relation Between Perceived Benefits and Obesity Prevention Action Perceived benefit is the} respondent's belief toward advantages they will get if they perform obesity preventive action. The cross-tabulation displayed in Table 1 reveals that just 56\% of the respondents received the advantages in performing obesity prevention action. Nevertheless, there is a relation between Perceived Benefits and obesity prevention action, with $P$ Value is 0.037 (P Value <0.05).

According to this study, respondents receives the advantages from working out, consuming vegetables and fruits, having breakfast, taking meals from home, and regular consumption of mineral water. It is supported by a research conducted in 2015 which stated that there is a connection between advantages felt by subject and consuming mineral water, the average subject reported that they drink water as much as 8-9 glass of water every 24 hours (Vaitinadin, 2015).

Respondents who feelt no advantages inform that by reducing time in watching television, or playing computer/game, it could prevent them from obesity. Lack of physical activity in daily life could lead people to experience obesity more often among children. The development of technology forced children to spend their time watching television or playing video games. The previous study mentions that the duration of screen time is known as one factor that could make children, between 5-6 years old, experience obesity. Children between 5-6 years old who spent more than two hours screen time in a day will have higher risk as much as 5,9 times bigger than those who had less than two hours screen time in a day (Pavilianingtyas, 2017).

The Relation Between Perceived Barriers and Obesity Prevention Action

Perceived Barriers is a belief of a negative aspect that becomes obstacles for respondents in preventing obesity. The cross-tabulation between Perceived Barriers and obesity prevention action displayed in Table 1 reveals that $51 \%$ of the respondents experience obstacles in preventing obesity but still performed it very well. Moreover it shows that there is no correlation between both of them, with $P$ Value of 0.255 ( $P$ Value $>0.05)$.

The obstacles are fast food, infrastructure availability, price, food choice, technology, family and friend support. The pattern of fast food consumption is majorly occurs among elementary school students (62.5\%) (Junaidi and Noviyanda, 2016). Those factors could affect someone in doing an obesity prevention action, it depends on the subject whether he will turn them into obstacles or not in implementing the program.

Physical activity is one of the interventions regarding obesity. Both home and school environment must play their role by providing physical activity to children. Many factors can lock that activity. According to a study in 2016, it is stated that the amount of physical activity among elementary school students is determined by obstacles experienced by subjects such as a fear to meet with strangers outside of school or home, bad weather condition, or tons of homework that must be finished (Rezapour, Mostafavi and Khalkhali, 2016). 
In addition to environmental support, parental support also has an important role to overcome obesity in children by providing support for a healthy lifestyle and a variety of support to overcome obesity. Most parents incorrectly label about overweight or obese children, parents assume that the children have a healthy weight. Tlt is caused by the uncertainty and lack of knowledge about healthy food, portion sizes, lacks of activity, obesity trends and health risks (Vittrup and McClure, 2018).

\section{The Relation Between Self Efficacy and Obesity Prevention Action}

Self Efficacy is a self-confident ability to take and make a decision. In this study, the self-ability will be mainly the inability of respondents while dealing with obesity prevention action. The crosstabulation between Self Efficacy and obesity prevention action displayed in table 1 reveals that 48 respondents (46.2\%) thought that they are able to perform obesity prevention action and apply to daily basis. There is correlation between both of them with $P$ Value of 0.037 (P Value<0.05).

Respondents have full ability to perform obesity prevention by reducing sweet dishes and beverages, consuming vegetables and fruits 2-3 portion in a day, and working out every Sunday. By consuming such a balanced menu, vegetables and fruits can prevent someone to be overweight. Vegetables and fruits have low calories; it becomes a very effective way to prevent overweight and obesity. According to Balanced nutrition guidelines by the directorate of people's health, it recommends people to consume 2-3 portions of vegetables in a day.

There were still $52.9 \%$ respondents who are unable to perform obesity preventive action. The respondents who can not perform obesity prevention action stated that they could not struggle to buy fast foods with a lot of fat, outside their school and house. This phenomena is supported by a finding in 2017, that children at the age of 5-6 who have fast food consumption more than three times in a week had obesity risk as much as 3,8 higher compared to those who consumed fast food less than three times in a week (Pavilianingtyas, 2017). Pattern and habit of dietary can be done by consuming vegetables and fruits, reducing consumption of sweet beverages and dishes, cutting the consumption of food with high fat and calories, fast-food diet, and increase physical activity (Kementerian Kesehatan RI, 2012). Based on that information, family especially mother should plan healthy diet for their children.

\section{The Relation Between Cues To Action and Obesity Preventive Action}

A cues to action is a factor outside of the individual desire. It is a strategy prepared to take action through information gathering, illuminating people's awareness by using an alarm system which is effective to motivate people in performing obesity prevention action (Glanz, Rimer and Viswanath, 2008).

The cross-tabulation between Cues to Action and obesity preventive action displayed in table 1 reveals that there are 54 respondents (51.9\%) who are motivated to perform this action and apply it very well in their daily life. In this study, it shows that the biggest factor that could motivate respondents in performing obesity prevention action is parental support, 99 respondents agreed to this choice $(95 \%)$, another choose medical professional (84\%), and the rest think that teacher is the best role model $(82 \%)$. The role of parents are crucial in providing balanced nutrition, managing diet and supporting physical activities such as sports as an effort to lose weight (Mariam and Larasati, 2016).

It is not only parents who are responsible for this action. The role of teacher while students are in school is also important in promoting healthy lifestyle by supporting physical education for all students approved by headmaster. The synergy between parents and teachers are expected to bring a good change in daily life of children by limiting consumption of sweet dishes and providing vegetables and fruits for breakfast and lunchtime (Ulilalbab, Enggar, Iga 2017).

This study reveals that the school administration of DR. Soetomo V Surabaya elementary school already It is not only parents who are of the balanced and healthy menu, mass physical training every Friday morning, football, volley, and fencing sport. This agenda should be 
implemented regularly and improved well.

\section{CONCLUSION}

Preventive behavior for obesity in elementary school students in research location is good. The statistical shows that the perceived benefits and selfefficacy are related to preventive behavior for obesity among the students at Dr. Soetomo V Elementary School. This study explains that the perceived benefits of exercise, consuming vegetables and fruits, having breakfast, taking meals from home, and regular consumption of mineral water. Respondents also have the ability by trying to reduce sweet foods and drinks, consume fruits and vegetables 2-3 servings a day, and exercise every week.

\section{REFERENCE}

Amalia, R. N., Sulastri, D. and Semiarty, R. (2016) 'Hubungan Konsumsi Junk Food dengan Status Gizi Lebih pada Siswa SD Pertiwi 2 Padang', Jurnal Kesehatan Andalas, 5(1), pp. 185-190.

Delisle, H., Ledoux, M. and Strychar, I. (2014) A practical guide for planning obesity prevention programmes among school-age children and adolescents in developing countries: a TRANSNUT Initiative, University of Montreal, Quebec, Canada.

Glanz, K., Rimer, B. K. and Viswanath, K. (2008) Health Behavior and Health Education Theory, Research, and Practice. doi: http:/ /hdl.handle.net/2027/spo.1038 1607.0007.102.

Junaidi, J. and Noviyanda, N. (2016) 'Kebiasaan Konsumsi Fast Food terhadap Obesitas pada Anak Sekolah Dasar Banda Aceh', AcTion: Aceh Nutrition Journal, 1(2), p. 78. doi: 10.30867/action.v1i2.14.

Kementerian Kesehatan Republik Indonesia (2013) Riset Kesehatan Dasar. Jakarta.

Kementerian Kesehatan Republik Indonesia (2018) Riset Kesehatan Dasar 2018. Jakarta: Kementerian Kesehatan Republik Indonesia.

Kementerian Kesehatan RI (2012) Pedoman Pencegahan Dan Penanggulangan Kegemukan Dan Obesitas pada Anak Sekolah,
Kementerian Kesehatan Republik Indonesia.

Kosnayani, A. and Aisyah, I. (2016) 'Faktor Risiko Yang Berhubungan Dengan Obesitas Remaja', Siliwangi, 2(2), p. 128.

Lapau, B. (2012) Metode Penelitian Kesehatan: Metode Ilmial Penulisan Skripsi, Tesis, dan Disertasi, Yayasan Pustaka Obor Indonesia. doi: 10.1016/j.trsl.2012.09.001.

Mariam, D. A. and Larasati, T. A. (2016) 'Obesitas Anak dan Peranan Orangtua', Medical Journal of Lampung University, 5(5), pp. 161165.

Nisak, A. J. and Mahmudiono, T. (2018) 'Pola Konsumsi Makanan Jajanan di Sekolah Dapat Meningkatkan Resiko Overweight/Obesitas Pada Anak', Jurnal Berkala Epidemiologi, 5(3), pp. 311-324. doi: 10.20473/jbe.v5i3.2017.

Pavilianingtyas, A. (2017) 'Faktor agen, pejamu, dan lingkungan kejadian obesitas pada anak usia 5-6 tahun', Jurnal Gizi Indonesia, 5(2), p. 105. doi: $10.14710 /$ jgi.5.2.105-111.

Prihaningtyas, R. A. et al. (2018) 'Anak Obesitas Dampak pada Kesehatan dan Perkembangan', Gramedia Jakarta.

Rezapour, B., Mostafavi, F. and Khalkhali, H. (2016) "“Theory Based Health Education: Application of Health Belief Model for Iranian Obese and Overweight Students about Physical Activity" in Urmia, Iran', International Journal of Preventive Medicine, 7, p. 115 . doi: 10.4103/2008-7802.191879.

Rodríguez-Ventura, A. L. et al. (2014) 'Barriers to lose weight from the perspective of children with overweight/obesity and their parents: A sociocultural approach', Journal of Obesity, 2014.2 doi: $10.1155 / 2014 / 575184$.

Rosyidah, Z. and Ririn Andrias, D. (2015) 'Jumlah Uang Saku Dan Kebiasaan Melewatkan Sarapan Berhubungan Dengan Status Gizi Lebih Anak Sekolah Dasar', Media Gizi Indonesia, 10(1), pp. 1-6.

Vaitinadin, N. S. (2015) 'The Ability Of The Health Belief Model To Predict Childhood Obesity Prevention BehaviorsAmong Upper Elementary School Children In India', Journal of Chemical Information and Modeling. doi: $10.1017 /$ CBO9781107415324.004. 
Vittrup, B. and McClure, D. (2018) 'Barriers to childhood obesity prevention: Parental knowledge and attitudes', Pediatric Nursing.

WHO (2010) Nutrition Landscape Information System (NLIS) COUNTRY PROFILE INDICATORS Interpretation Guide, WHO Press. doi: 10.1159/000362780. Interpretation.

Wulandari, S., Lestari, H. and Fachlevy, A. F. (2016) 'Faktor yang Berhubungan
Dengan Kejadian Obesitas Pada Remaja di SMA Negeri 4 Kendari Tahun 2016', Jurnal Ilmiah Mahasiswa Kesehatan Masyarakat, 1(3). doi: 10.1039/CT9089300741.

Yaqin, M. K. and Nurhayati, F. (2014) 'Prevalensi Obesitas Pada Anak Usia SD Menurut IMT/U Di SD Negeri Ploso II No 173 Surabaya', Jurnal Pendidikan Olahraga dan Kesehatan, 02(173), pp. 114-118. 